\title{
COMMODITIES SPACE FOR SOCIAL INTERACTION IN THE KAMPUNG AROUND CAMPUSES AT JAKARTA
}

Case Studies : Public Open Space at Kampung around Tarumanagara and Bina Nusantara University

\author{
Ramos P Pasaribu*, Uras Siahaan**, Rumiati Rosaline Tobing*** \\ *) Doctoral Student of Architecture of Parahyangan University, Christian University \\ of Indonesia Jl. Mayjen Soetoyo, Jakarta \\ **) Promotor, Sekolah Pasca Sarjana Jl. Merdeka no.30, Bandung, Indonesia \\ ***) Co-Promotor, Sekolah Pasca Sarjana Jl. Merdeka no.30, Bandung, Indonesia \\ e-mail: ramos.arsitekview@yahoo.com
}

\begin{abstract}
An interesting phenomenon in Indonesia today is that "life coexisting between urban centers with urban village features is another face" (Emil Salim, 1984), things such as those occurring in DKI Jakarta where universities are growing alongside the surrounding kampung.

Student activities melt into the kampung to meet their daily needs such as a boarding house (kos-kosan), food, and so on coloring the social interaction space. Not all the kampung that grow together with the surrounding campus have a better change in the space of social interaction. But there are kampungs that experience better economic change which then affect the changes in social interaction space.

This study aims to find a kampung in which there is social interaction space in the commodity space dominated by trade homogeneity with the criteria of the settlement of population density $>400$ persons/ha has direct achievement from kampung to campus, more kampung formerly existed rather than campus, open kampung type. At a radius of $400 \mathrm{~m}$ from the campus there is a building function dominated by trade activities, student activities along the way, and commodification of public open space.

Research method using case study, found kampong around the campus where kampung Grogol and Kemanggisan are selected as kampung that has homogeneity of trading activities (commodity space) and heterogenity of college student activities. In it happens the production of (new) social interaction space that produced by the relation between the aspects that effect of commodity space and various of college student activities in kampung.
\end{abstract}

Keywords: Change Kampung, Social Interaction Space. 


\section{INTRODUCTION}

An interesting phenomenon in Indonesia today is that "life coexisting between urban centers with urban village features is another face" (Emil Salim, 1984). As an example of what happened in DKI Jakarta as an industrial, trade, maritime and educational center, or as a city with dual main function (Differcified Cities) which declare itself as "indamardi city (industry, trade, maritime \& education) as well as the center of government. (A. Muktiono, 2005).

A reality that occurred in DKI Jakarta where there is a college (education center) with its surrounding kampung that need each other (Workshop Department of Architecture Untar, 2012), as seen in the kampung Grogol in around the campus of Tarumanagara University in Jakarta.

In the coexistence of universities with the surrounding kampung there arose a phenomenon that is the melting of college student activities in the township to meet the needs of everyday life such as foraging, photocopying, boarding house or "koskosan (guesthouse, rental house/room/space for college student in kampung)" (Study results show the percentage of students living in kampung reach $51 \%$ the number of residents (of the kampung (Elly Mulyana, Haryo Winarso, 2016), etc. As time passes, campus settlements tend to experience spatial changes as seen in the figure 1.
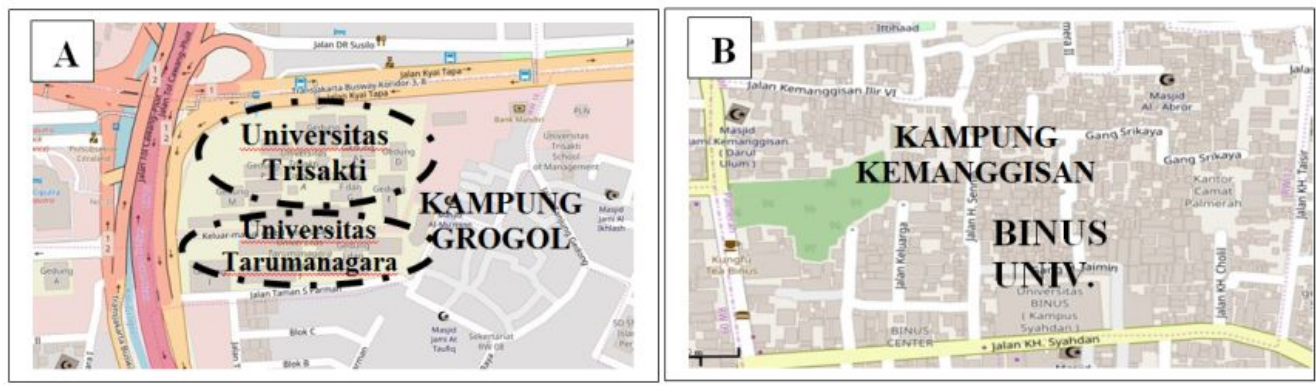

Figure 1. In the coexistence of universities with surrounding kampong in Jakarta ; (A) Kampong grogol around Tarumanagara University, (B) Kampong Kemanggisan around Binus Source: field survey, 2012

Spatial changes in the settlement affect the changes in spatial structure. Aspects of spatial structure can be reviewed and traced through three aspects (Amos Rapoport, 1993), namely: 1. social structure, 2. economic structure, 3. physical structure and activities.

\section{Background Economic Changes In the Kampung}

With the increasing demand for everyday college student needs such as boarding houses, eating places, photocopiers and so on, the value and function of land in the kampung in around the campus increases towards the commodification of its public open spaces and many people sell their house. New houseowners tend to change the function of buildings for trading activities and with other residents trade to provide 
for college student needs, and the occurrence of new social interaction space based on production and consumption relationships between college students and residents/traders.

\section{Background Social Change In the Kampung}

The economic growth in the kampung surrounding the campus resulting in production and consumption relations between the population/traders and students impacted the dialectics of social change such as activities that are usually done spontaneously into planned, social relations changes between citizens into relationships between citizens/traders with college students, among traders, between sellers and buyers of services. The social relations of the trade will produce their activities and social interaction space.

\section{Background Cultural Changes In the Kampung}

During the process of melting college student activities into the village to find what is needed everyday tend to be consumptive to services that are easily accessible and economical.

College student consumptive culture tends to change the culture of villagers (urban kampung) from traditional culture to productive culture serving the needs of the college students as well as seeking profits for changes in the value and function of the building and welfare of citizens dominated by trading activities and even homogeneous activities that tend to trade.

Cultural change becomes a daily social practice (between productive and consumptive cultures) that shapes the culture based on the reality of life or social practice between the college students and the daily citizens called a profit-oriented culture production. Culture produces new activities resulting from relationships between college students and citizens such as opening food stalls in the yards, on the street/on the edge of the alley, open a coffee shop, and so forth. College students produce needs for daily life, citizens/traders produce services to meet the needs of everyday college students.

\section{Background Physical Changes In the Kampung}

Physical changes of buildings in the kampung toward the vertical background by changing the function of residential houses into boarding houses (kos-kosan), workshops, food stalls, and so on). Based on a study, the change is like a guesthouse business (kos-kosan) reaches 30\%, business stalls reach $23 \%$, workshop business reaches $12 \%$ and $35 \%$ homes that do not have business (Elly Mulyana.Haryo Winarso, Tth).

Other physical changes in public spaces such as changes in spatial arrangement and elements of public open space formed based on the interests of capital owners and businesses of citizens and college students, and changes in green areas such as the increasingly crowded buildings then reduce the green space before.

The physical changes of the kampung in around the campus may vary, some are changing towards a worse quality of social space but there is also a better direction of the quality of social space.

\section{Distress, Phenomenon and Issues}

The existence of knowledge of citizens to the high value and function of land in around the campus so that the optimization of physical development, 
commodification of space (open spaces public rent), and homogeneity of trade activities on the function of the building. This will certainly affect how the changes in social interaction space.

From an architectural point of view, the change raises an interesting architectural phenomenon, namely that in the kampung in around the campus there is always a "Social Space Change". Based on the phenomenon, the issue raised in this research is the existence of "Commodification of Public Open Space" on the front yards house.

This issue is very important because in the township of "Social Interaction Space" is vital and very necessary considering the kampung is a community, and according to (Dinas Perumahan Provinsi DKI Jakarta, 2006) that "The urban kampung can be said to represent the complexity of urban problems".

\section{Identification of Problems}

In this study, from the occurrence of social space changes in the commodity space at the kampung in around the campus, it can be identified that the commodity space occurring within the kampung in around the campus will affect the college student activities in the space of social interaction within it.

\section{Formulation of the Problem}

The existence of the relation between the aspects that effec of commodity space (population density, the optimization of land use for physical development (vertically/horizontally), changes in land use (domicile to the mixture of trade, dominance homogeneity of trade activities, dominance heterogeneity of college student activities in public open space which is dominated by the main/necessary activities rather than any other type of activities (specific, additional/option, symbolic, social activities, etc).

\section{Focus Issues}

The focus of the problem on the kampung that dominated the commodification of public open space on the front yards house among the kampung residing in nine colleges in Jakarta.

\section{Novelty Research}

Through the approach of theory of social space production (lefebvre) obtained one of nine kampung in around the campus that has a new perception (shown through daily action) houseowners on the function of the building and its front yards house based on social relations trade between college students and non students will produce social interaction space in the commodity space at the kampung in around the campus.

\section{Premise and Work Test}

A premise in this study, that in urban kampung living side by side with universities always need each other and cause melting of college student activities within the kampung. Due to the melting of college student activities in the kampung there is a "Change of Social Space".

Based on the premise, the work test raised in this study is the change of social space for trading activities in the kampung in around the campus to produce new 
social interaction space, so that the creation of social interaction space in the commodity space in the kampung.

Based on the analogy of the meaning of a house according to John F.C. Turner (1976: 151), where the house has two meanings ; as a noun (product/commodity) and as a verb (process/activity), then a commodity space is affected by population activity/population density. There is optimization of land use for physical development (vertically/horizontally), changes in land use (from housing function to mixed-house housing, dominant homogeneity of trade activity and heterogeneity of college student activity), while college student activity aspect is affected by types of activity.

\section{THEORY / RESEARCH METHODS}

\section{Research Question}

1. How is the kampung selection process among the nine kampung in around the campus that meet the criteria for kampung selection dominated by commodity space?

2. How does the collapse of government discourse on the function of land for housing becomes a function of housing and trade mixture in the kampung in around the campus.

3. How does the process of creating social interaction space in the commodity space in accordance with the function of buildings in the kampung in around the campus?

\section{Research Purposes}

Finding the production of social interaction space in the commodity space of among the nine kampung located in about nine campuses in Jakarta whose houseowners have new perceptions of the building's function and the front yards house for tradesocial relations between college students and non students.

\section{Research Benefits and Contributions}

The results of this study are expected to be useful for the science of environmental architecture to know how new college students interact socially with their environment in the space of social interaction produced by the commodity space in the kampung in around the campus.

To achieve the objectives required study of theories that started from the theory of the kampung, about environmental architecture, about space in architecture, social space and the production of social space.

The framework of the theory of social space as a whole confronts the theory of re/production of social space (Henri Lefebvre), as shown below.

\section{Understanding of the Urban Kampung}

The urban kampung (according to Y Basuki, Nurtarti Soewarno, 2005) says that kampung usually consists of physical elements and social elements, built spontaneously by the people themselves and have comfort. In terms of achievement, 
the kampung can be classified into 2 different types (Prof. Sandi Aminuddin Siregar, 1990), namely:

1. Closed pocket areas type or closed type; that has only one achievement to the pockets of the kampung.

2. Open pocket areas type or open type; ie having two or more achievements from different sides to the pockets of the kampung.

\section{Definition of Environmental Architecture}

In the context of environmental architecture (according to Haryadi, 1995), that environmental architecture put more emphasis on architectural relations with its environment, ... The dimensions of the environment can also be divided into three groups: the physical environment, the social and cultural environment.

While the understanding of the environment in the context of architectural space (according to Uras Siahaan, 2013) is that "The environment can be viewed as a series of relationships between elements and people, where the relationship has patterns and structures. The relationship between these objects in the environment is primarily space."

Thus, the architecture of the environment is the organization of space from the dimensions of the physical, social and cultural environment, time, meaning, ability to accommodate activities, and has a pattern and structure of relationship/communication that is the space between people with people, between people with objects, between objects with objects, as well as outer space elements.

\section{Understanding of Space In Architecture}

Space (according to Lefebvre, Paul C Adams, 2006), says that "Lefebvre argued that space is produced, the space is not finalized, space is produced, consumed, and reproduced in the never ending and itterative process". Empty space filled/consumed by the body (human activities), producing and reproducing their space, and so on without stopping.

\section{Understanding of Social Interaction Space In Architecture}

Social space is a real space based on social reality, is a container/space to meet the needs for social interaction activities. As said (according to Henri Lefebvre 2000.26; Arie Setyaningrum Pamungkas, 2016), it says: "Space is real in the same sense that commodities are real since (social) space is a (social) product".

\section{Understanding of Production and Re/production of Social Space (Henri Lefebvre)}

In the production of social space (Henri Lefebvre) offers a triadic concept in the production of social space. In whole or in whole, the way the triadic concept works can be seen like the figure 2 . 
In this study public open space such as on the front yards house and the street is perceived by the houseowners or citizens as a container that can produce profits to trade, thus creating/produced leased space for trading on the front courtyard house (for commodity space), and also created activities social interaction between college students and traders in trading activities or reproducing the social interaction space within the produced commodity space.

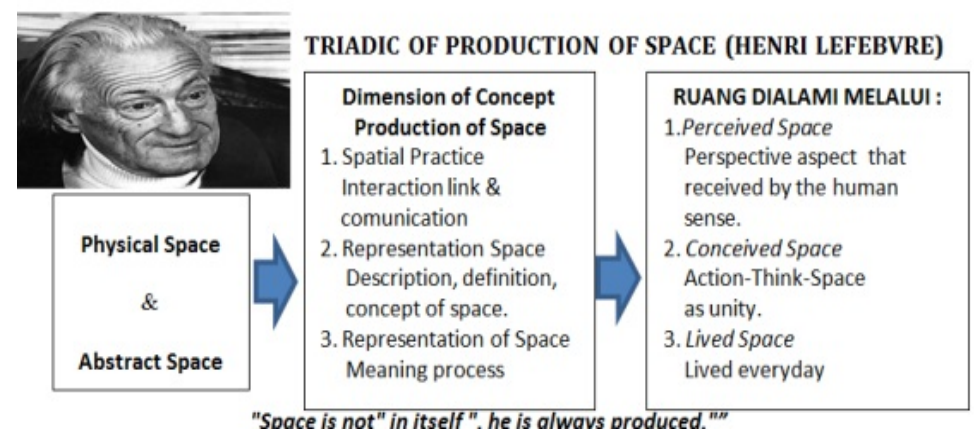

Figure 2. Triadic Concept of Production of space (Henry Lefebvre). Source: field survey, 2012

\section{Types of Social Interaction Activities}

Some outdoor activities according to (Jahn Gehl, 2010) among others necessary, optional, and social activities and acoording to (Amos Rapoport, 1977, p. 19) among others : the activity proper.; 2 . the specific way of doing it, additional, symbolic activities. In this research, necessary activities and the activity proper can be said as the main activities. The dominance of activity in this study is the main activities like daily needs ; foraging, laundry, go/from the campus, typing/photocopying near where they live or campus.

\section{Research Method}

Considering the research objectives and the interrelationships between cases, there are research variables that can already be shown, placing the object of the study as the case, as well as the research question "how" in the research question, then selected research qualitative methods (according Singarimbun and Effendi, 1995) research variables with hypothesis tesa test/preposition is explanatory case study research method.

\section{Sampling}

Taking into account the tendency of various research objects, the type of sampling in the study is the maximum variation type with the aim of being able to document the diversity of places based on specific characteristics. Researchers took six different case research objects. 


\section{RESULTS AND DISCUSSION}

\section{Analysis of Kampung Location Selection as Research Object}

The nine kampung in around the nine university campuses in Jakarta are selected based on the criteria of having more than one achievement (Figure 3). The kampung first existed rather than the campus. There is a commodification of its public open space, the heterogeneity of student activities within the kampung, the dominance of trade activities, the direct achievement from kampung to campus, college student activities in the kampung. The following can be shown the process of each analysis on the kampung in around the nine university campuses.

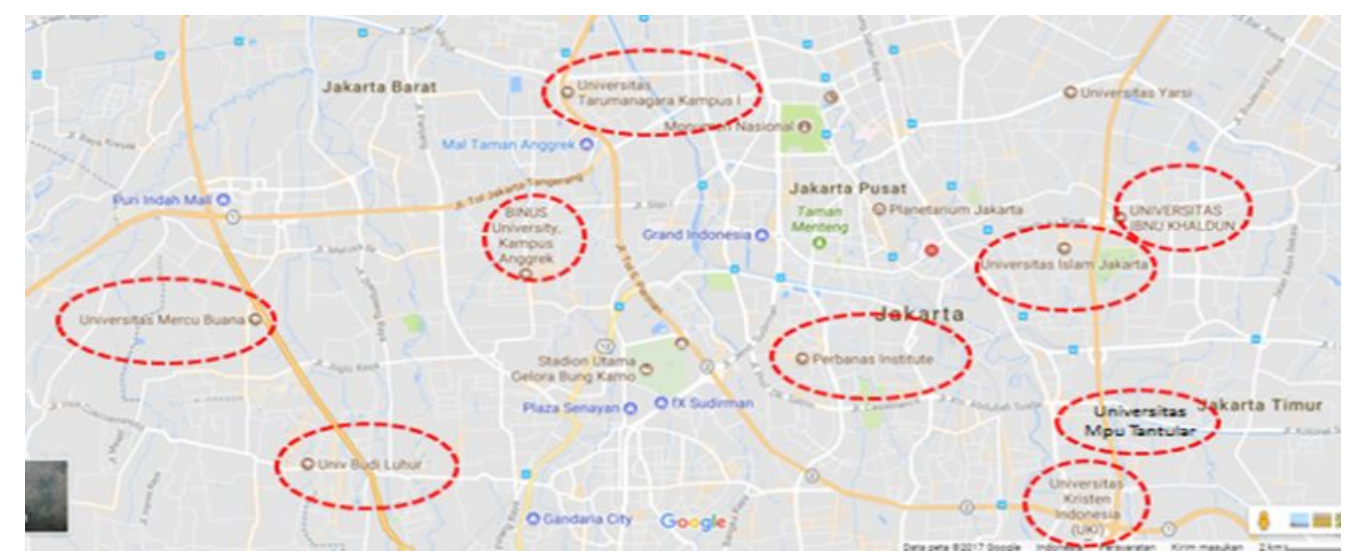

Figure 3. Location of nine university in this research.

Source: google map, 2012

Table 1. Analysis of kampung location selection as case study.

\begin{tabular}{|c|c|c|}
\hline g Alt & Selection Criteria & Selection Analysis \\
\hline$=(1)=$ & $\begin{array}{l}\text { Kampung's Type: } \\
\text {-Open Type: has more than } 2 \\
\text { achievements to the kampong. } \\
\text {-Exist first rather than college. } \\
\text {-The commodification of } \\
\text { public open space and } \\
\text { homogeneity of space occurs } \\
\text { by trade activities. }\end{array}$ & $\begin{array}{l}\text { Analysis : } \\
\text {-Kampung is } \\
\text { dominated by college } \\
\text { student activities. } \\
\text { - Commodities occur } \\
\text { in public open space } \\
\text { and homogeneity of } \\
\text { space by trade }\end{array}$ \\
\hline 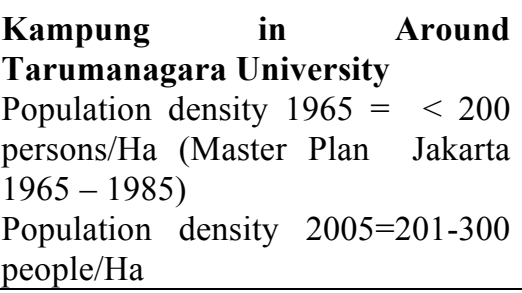 & $\begin{array}{l}\text { commercial / commercial } \\
\text { activities. } \\
\text {-Have a direct achievement } \\
\text { from campus to kampung. } \\
\text {-Kampung is dominated by } \\
\text { college student activities. }\end{array}$ & $\begin{array}{l}\text {-Kampung is } \\
\text { dominated by college } \\
\text { student activities. } \\
\text {-Commodities occur in } \\
\text { public open space and } \\
\text { homogeneity of space } \\
\text { occurs by trade. }\end{array}$ \\
\hline
\end{tabular}


Table 1. Analysis of kampung location selection as case study (continued)

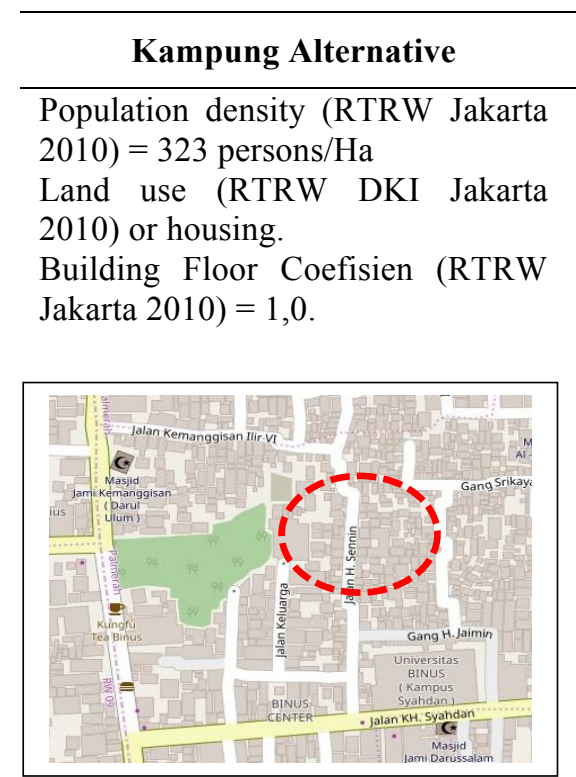

Kampung in Around Binus University

Population density $1965=0$ persons/Ha (Master Plan Jakarta 1965-1985).

Population density $2005=201-300$ persons/Ha

Population density (RTRW Jakarta 2010) $=422$ persons $/ \mathrm{Ha}$

Land use (RTRW Jakarta 2010) = Housing.

Building Floor Coefisien (RTRW 2010) $=1,0$

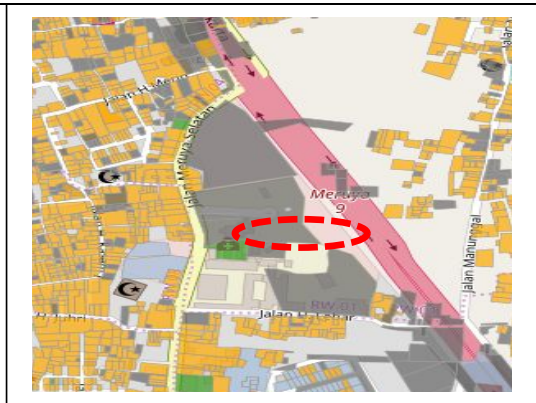

Kampung in Around Mercubuana University

Population density $1965=0$ persons/Ha. (Master Plan Jakarta 1965 - 1985)
Kampung's Type:

-Open type: has more than 2 achievements to the kampung. -Close there first rather than college.

-The commodification of public open space and homogeneity of trading activities.

-Occurs dominance of commercial/commercial activities.

-Have a direct achievement from campus to kampung. -Kampung is dominated by college student activities.

\section{Selection Analysis}

activities

\author{
Analysis : \\ -Kampung is \\ dominated by college \\ student activities. \\ - Commodities occur \\ in public open space \\ and homogeneity of \\ space by trade \\ activities. \\ -Kampung is \\ dominated by college \\ student activities. \\ - Commodities occur \\ in public open space \\ and homogeneity of \\ space occurs by trade \\ activities.
}

\section{Kampung's Type: \\ Analysis :}

-Open type : has more than 2 achievements to the kampung. -Close there first rather than college.

-Became a low commodity space.

-Not a homogeneity of dominated trade space. -Have a direct achievement from campus to kampung. -Kampung is not dominated by college student activities.
-Kampung is not dominated by college student activities. -No commodities occur in public open space and no homogeneity of space occurs by trade activities. 
Table 1. Analysis of kampung location selection as case study (continued)

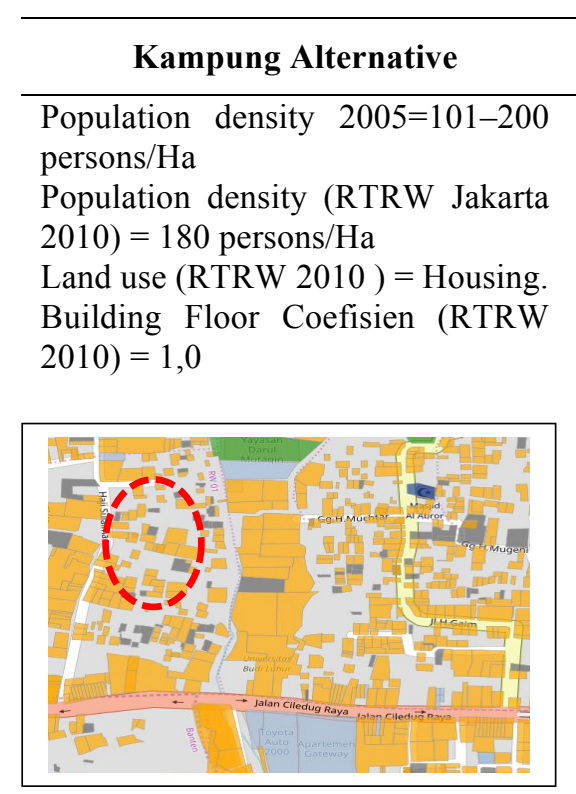

Kampung in Around

Budi Luhur University

Population density $1965=0$ persons/Ha. (Master Plan Jakarta 1965-1985).

Population density $2005=101-200$ persons/Ha

Population density (RTRW Jakarta $2010)=247$ persons $/ \mathrm{Ha}$

Land use (RTRW Jakarta 2010) = Housing..

Building Floor Coefisien (RTRW 2010) $=1,0$

\section{Kampung's Type :}

-Open type : has more than 2 achievements to the kampung. -Close there first rather than college.

-Have a direct achievement from campus to kampung.

-Kampung is not dominated by college student activities.

\section{Analysis :}

-Kampung is not dominated by college student activities. -No commodities occur in public open space and no homogeneity of space occurs by trade activities.

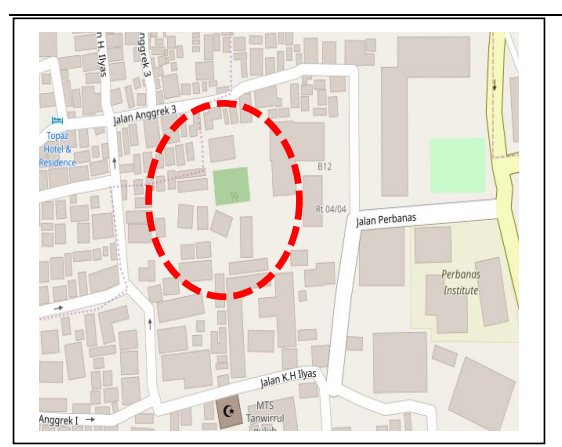

Kampung in Around PERBANAS University

Population density $1965=200-300$

\section{Kampung's Type:}

-Kampung Terbuka:has more than 2 achievements to the kampung.

-Close there first rather than college.

-The commodification of public open space and homogeneity of trading activities.

-Occurs dominance of commercial/commercial activities -Have a direct achievement

\section{Analysis :}

-Kampung is dominated by college student activities and office employees. -Commodities occur in public open space and homogeneity of space occurs by trade activities. 
Table 1. Analysis of kampung location selection as case study (continued)

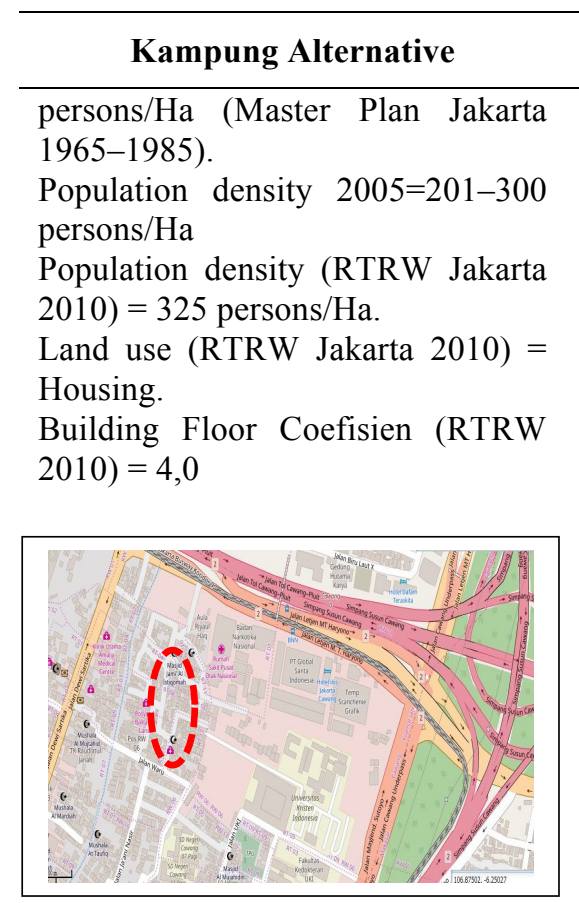

Kampung in Around Indonesian Christian University

Population density $1965=0$ persons/Ha.

(Master Plan Jakarta 1965-1985).

Population density 2005 $=201-300$ persons/Ha

Population density (RTRW Jakarta 2010) $=325$ persons $/ \mathrm{Ha}$

Land use (RTRW Jakarta 2010) = Housing.

Building Floor Coefisien (RTRW 2010) $=2,0$

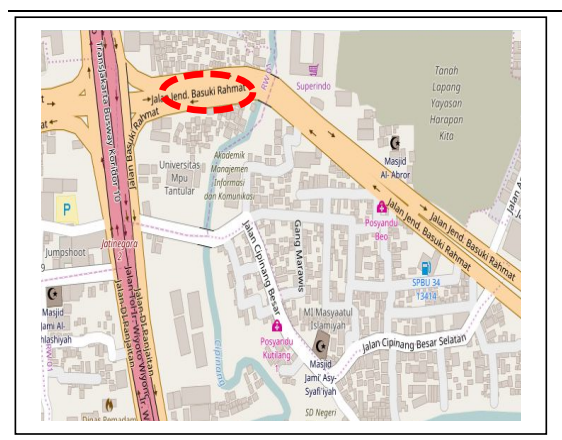

Kampung's Type:

-Open type : has more than 2 achievements to the kampung. -Close there first rather than college.

-Have a direct achievement from campus to kampung.

-Kampung is not dominated by college student activities

\section{Analysis :}

-Kampung is not dominated by college student activities. -No commodities occur in public open space and no homogeneity of space occurs by trade activities.

\section{Kampung's Type: \\ Analysis : \\ -Open type : has more than 2 achievements to the kampung. -Close there first rather than college. \\ -Have a direct achievement from campus to kampung. \\ -Kampung is not dominated by college student activities. \\ -Kampung is not dominated by college student activities. -No commodities occur in public open space and no homogeneity of space by trade activities.}


Pasaribu, Siahaan, Tobing : COMMODITIES SPACE FOR SOCIAL INTERACTION SPACE IN THE KAMPUNG AROUND CAMPUSES AT JAKARTA

Table 1. Analysis of kampung location selection as case study (continued)

\begin{tabular}{|c|c|c|}
\hline Kampung Alternative & Selection Criteria & Selection Analysis \\
\hline $\begin{array}{l}\text { Kampung in Around } \\
\text { Mpu Tantular University } \\
\text { Population density } 1965=<200 \\
\text { persons/Ha. (Master Plan DKI } \\
\text { Jakarta } 1965-1985 \text { ) } \\
\text { Population density 2005=201-300 } \\
\text { persons/Ha } \\
\text { Population density (RTRW Jakarta } \\
2010 \text { ) } 325 \text { persons/Ha } \\
\text { Land use (RTRW Jakarta 2010) }= \\
\text { Housing. } \\
\text { Building Floor Coefisien (RTRW } \\
\text { 2010) = } 1,0\end{array}$ & & \\
\hline
\end{tabular}

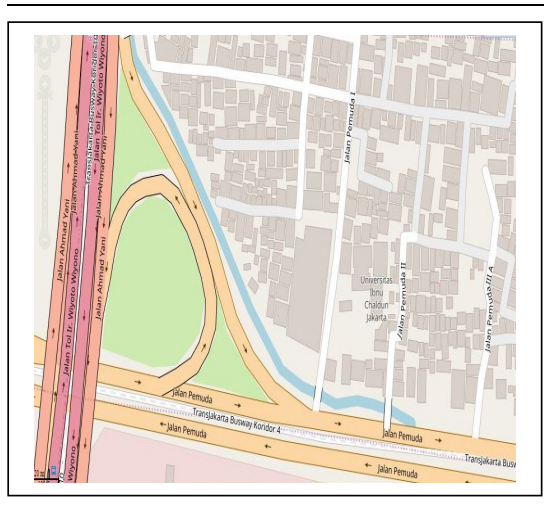

Kampung in Around Ibnu Qaldun

University

Population density $1965=<200$ persons/Ha. (Master Plan Jakarta 1965-1985).

Population density 2005 $=200-300$ persons/Ha

Population density (RTRW 2010)

$=325$ persons $/$ Ha.

Land use (RTRW 2010) = Housing. Building Floor Coefisien (RTRW 2010) $=1,0$

\section{Kampung's Type:}

-Open type: has more than 2 achievements to the kampung. -Close there first rather than college.

-Have a direct achievement from campus to kampung.

-Kampung is not dominated by college student activities. 
Table 1. Analysis of kampung location selection as case study (continued)

\begin{tabular}{|c|c|c|}
\hline Kampung Alternative & Selection Criteria & Selection Analysis \\
\hline 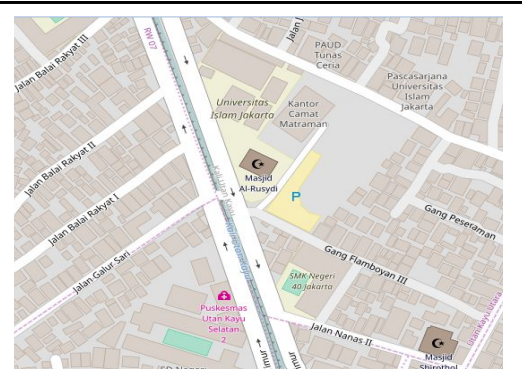 & $\begin{array}{l}\text { Kampung's Type: } \\
\text {-Open type: has more than } 2 \\
\text { achievements to the kampung. } \\
\text {-Close there first rather than } \\
\text { college. } \\
\text {-Have a direct achievement } \\
\text { from campus to kampung. } \\
\text {-Kampung is not dominated } \\
\text { by college student activities. }\end{array}$ & $\begin{array}{l}\text {-Kampung is not } \\
\text { dominated by college } \\
\text { student activities. } \\
\text {-No commodities } \\
\text { occur in public open } \\
\text { space and no } \\
\text { homogeneity of space } \\
\text { occurs by trade } \\
\text { activities. }\end{array}$ \\
\hline $\begin{array}{l}\text { Kampung in Around Jakarta } \\
\text { Islamic University } \\
\text { Population density } 1965=<200 \\
\text { persons/Ha. (Master Plan Jakarta } \\
\text { 1965-1985). } \\
\text { Population density } 2005=201-300 \\
\text { persons/Ha. } \\
\text { Population density (RTRW 2010) } \\
=253 \text { persons/Ha. } \\
\text { Land use (RTRW 2010) = Housing. } \\
\text { Building Floor Coefisien (RTRW } \\
2010 \text { ) = 1,0. }\end{array}$ & & \\
\hline
\end{tabular}

Source (Map) ; Landing Map Badan Pertanahan Nasional Republik Indonesia (http://BPN.go.id)

Kampung changes vary (depending on financial ability, knowledge, awareness, needs, etc.), so not all of the kampungs in around the nine universities in Jakarta (kampung in around Untar, Binus, Mercubuana, Budi Luhur, Perbanas, UKI, Mpu Tantular, Ibn Qaldun and the Islamic University of Jakarta) which made his kampung as a commodity/comodity space. For students who tend to be difficult to interact socially with the environment in the kampung will create a new college student social interaction space produced by trading activities, or created interaction social space for college students in the commodity space.

\section{Analysis Selection of Case Study Object}

The case study object was chosen based on the specific variation of the building function on the sides of the road, the adjacent building functions chosen as the case study object were: 
1. The function of the building as a typing (open/open always) facing the typing (open/always open) with the social interaction space between the street space and the space within the typing.

2. The function of the shop building (semi-open) and boarding house (kos-kosan) dealing with residential and boarding house (semi-closed/low transparent fencing) with social interaction space between road space of the fork of road with the front yards house.

3. The function of restaurant and boarding house (high fence/closed) faced with educational building (Kindergarten/semi open/transparent low fence) with social interaction space between the street space with the front yards house.

4. The function of the building where the restaurant and boarding house dealing with the boarding house (closed/massive fence) following shops inside (semiopen) with social interaction space between the road space with the boundary of the fence.

5. The function of the building as a food stall (semi-open) and retail traders in front of the shop (over the road) facing the boarding house (closed/high fence) with social interaction space between the street space with some space inside the food stalls.

6. The function of the building as a cigarette shop under a shade tree (open) with a place of photocopy and book binding (open/without fences) with social interaction space between the cigarette stall limit with space in the place of photocopy and book binding.

Of the six case study objects, the numbers 1 through 4 are in the kampung kemanggisan in around the campus of Binus University and the object case study number 5 and 6 are in the achievement to the kampung grogol in around Untar campus.

\section{Analysis of Government Discourse on Kampung Research Area. Based on the master plan DKI Jakarta in 1965 (Figure 4)}

Analysis from planning the function of research area (Untar) for unplanned housing (kampung). 

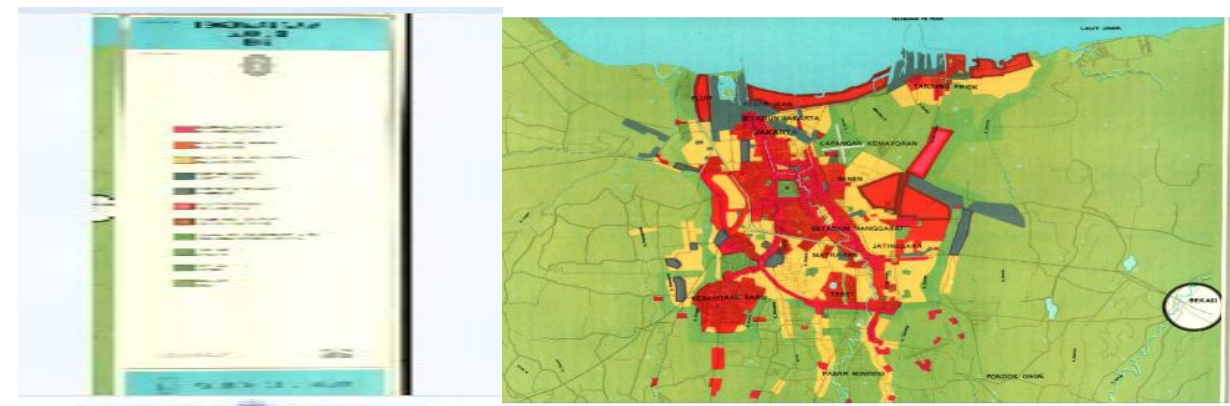

Figure 4. Master plan DKI Jakarta 1965 - 1985.

Source : Government of DKI Jakarta.

\section{Based on Detail Plan of Sub District Spatial Planning in 2005 (Figure 5)}

Land use plan for research area (in around Untar \& Binus) in 2005 is for guesthouse area dan facilities.

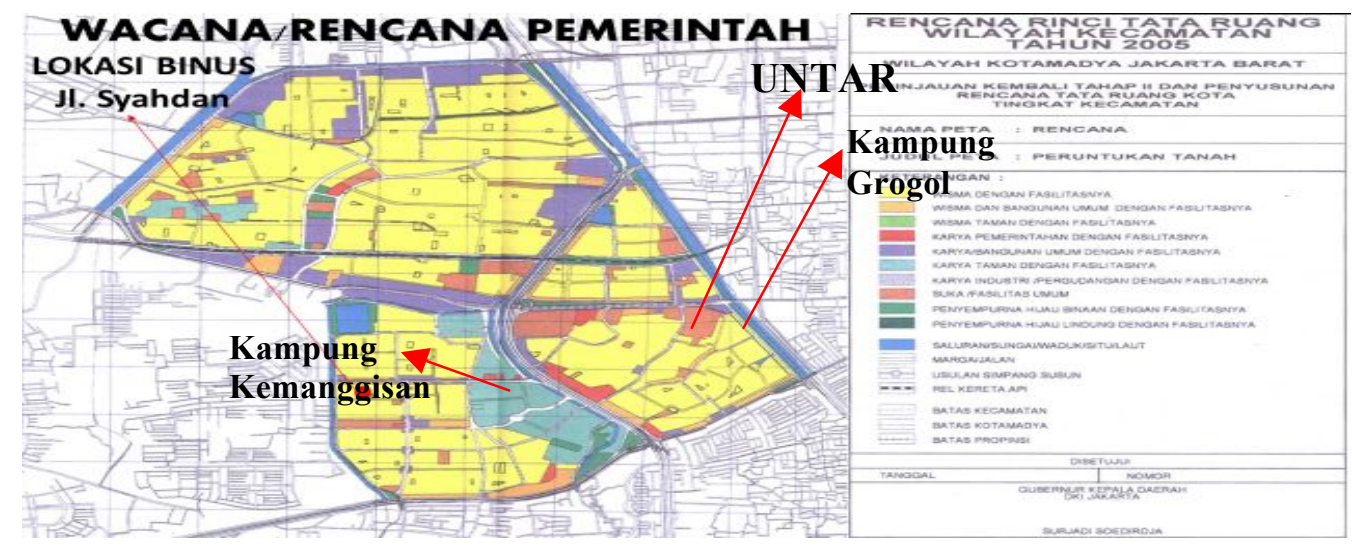

Figure 5. Detail plan of sub district spatial planning (West Jakarta) Source : Government of DKI Jakarta.

\section{Based on Municipal Spatial Plan DKI Jakarta in 2010 (Figure 6)}

Land use plan for research area (in around Untar) in 2005 is for housing. Land use plan for research area (in around BINUS) in 2010 is for housing.: 


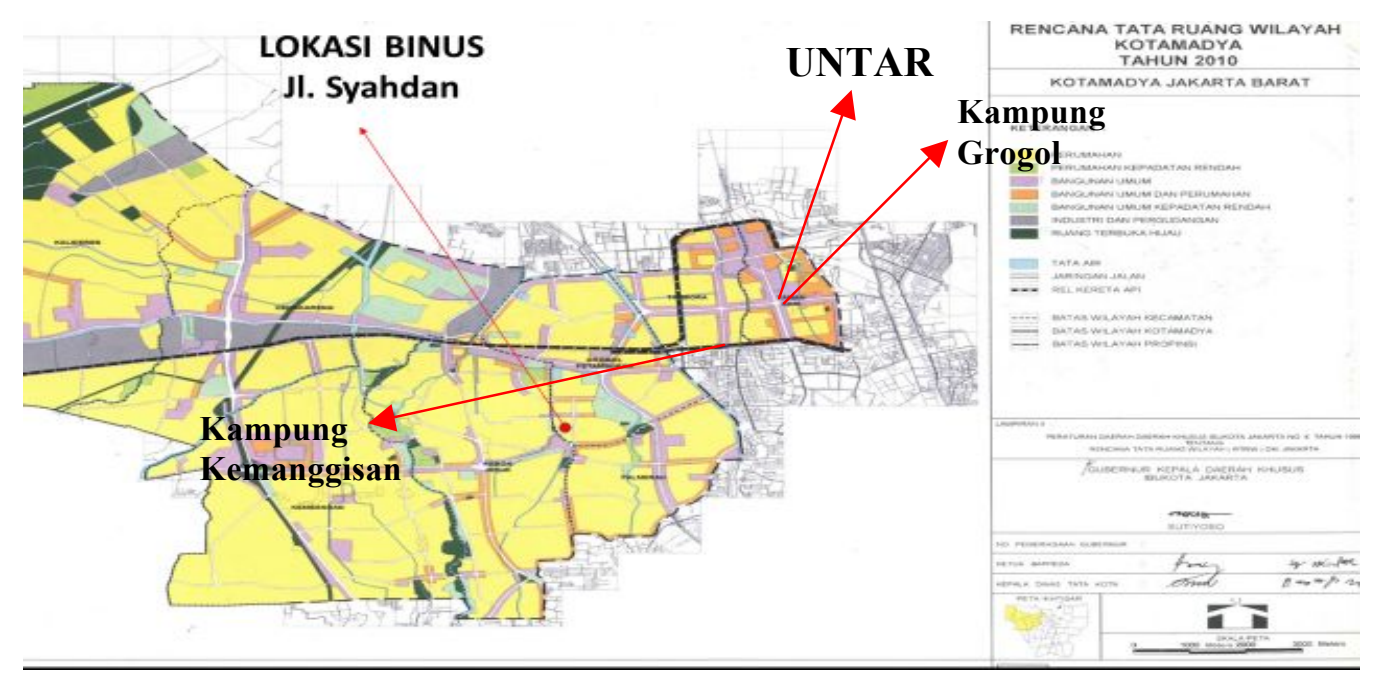

Figure 6. Municipal spatial plan DKI Jakarta (West Jakarta)

Source : Government of DKI Jakarta.

\section{Based on Zoning Plan Grogol Petamburan in 2015 (Figure 7)}

Land use plan for research area (in around Untar) in 2015 is for middle housing (R4).

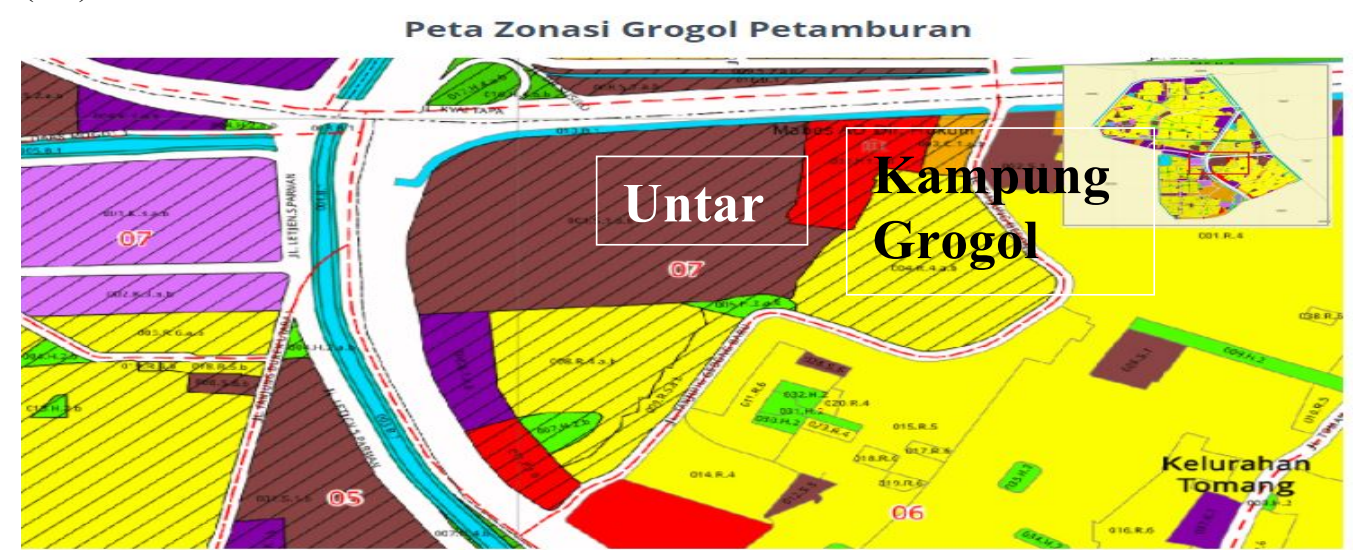

Figure 7. Zonning plan Grogol Petamburan

Source : Government of DKI Jakarta.

\section{Based on zonning plan for Palmerah district in 2015 (Figure 8)}

Land use plan for research area (in around BINUS) in 2015 is for middle housing (R4). 


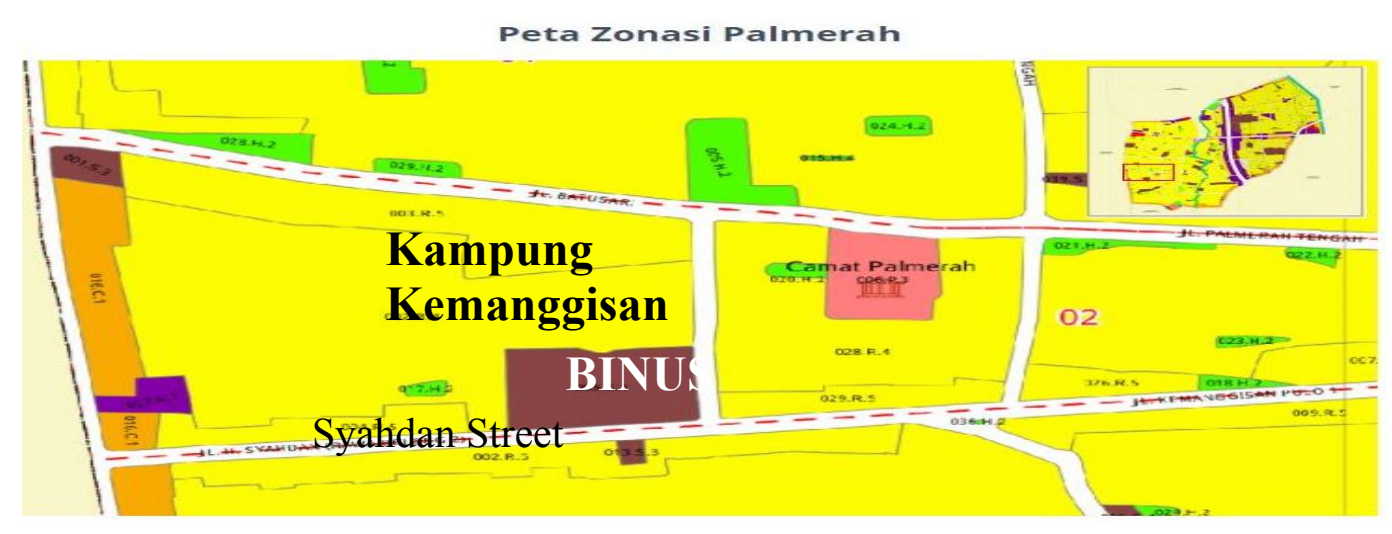

Figure 8. Zonning plan PALMERAH

Source : Government of DKI Jakarta.

\section{Analysis of House Owner's Discourse on Owned Building Functions}

The area of the settlement area around the campus which is discouraged by the government is different from what is abstracted by house owner/resident/capital owners/trader/environmental comunity, so the government's discourse collapses by the abstraction of the owner of the house or the owner of the capital where the abandoned area of the kampung is abstracted by the houseowner/resident into sub zone of the big house (R5) and sub zone of trading and low KDB services (K4) or mixed (C1).
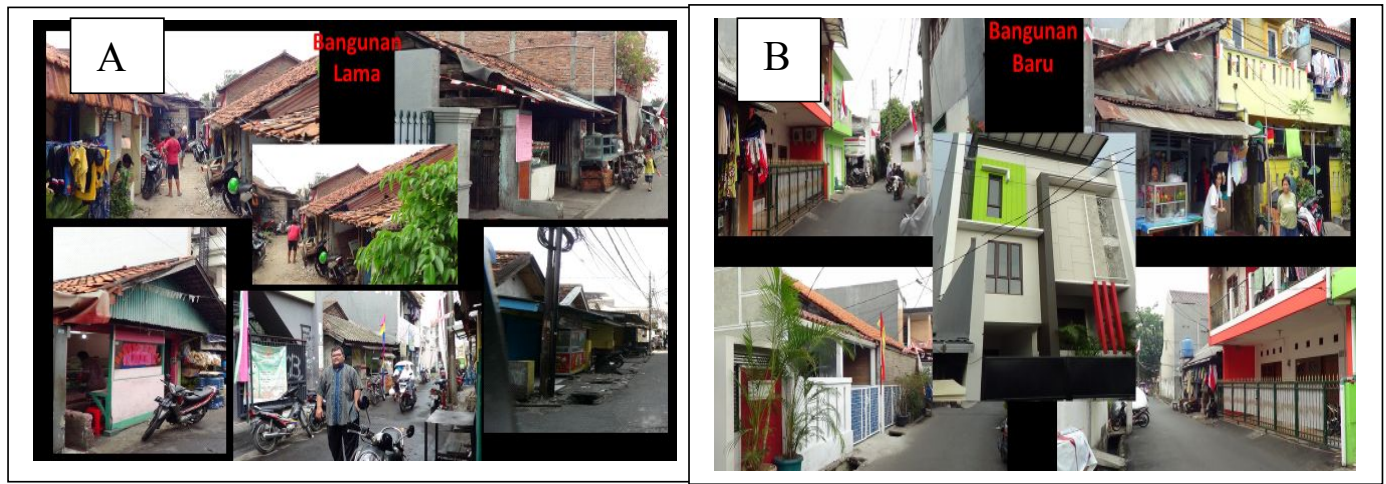

Figure 9. (A) Old building \& (B) New building (Owner's discourse on building function. Source : Field Survey, 2017

\section{Analysis of House Owner's Discourse on Front Courtyard House Function.}

Residential area discouraged by the government collapsed to the abstraction of the houseowner who changed the function of the building function from residence into a place to rent (kos-kosan), for retail, food stalls, laundry, shops and so forth. Neither on the front yards house should not be built because within the boundary line of the 
building (garis sempadan bangunan) was abstracted by the owner of the house or the owner of capital to be a retail shop, a laundry shop, food stalls, grocery stalls, and so forth.

\section{Analysis of Citizens and Government Discourse Every day About Public Open Space Functions}

Every day, the road area on the achievement to the campus (as in the street of $\mathrm{S}$ Parman park on the side of the campus of Untar is abstracted by traders, local residents and local environmental officials, green spaces become stalls (warungwarung) and shops as a place to sell food and coffee shop (warung kopi)/printing/binding. Abstraction of house owner/resident/capital owners/trader/environmental comunity on his/her house or space that can be assessed more due to besides the urgent need of the college student also because have profit for home owner/capital owners/trader/environmental comunity.

\section{Analysis of College Student Activities}

Every day (on active lecture), college student activities are dominated by the main activities in around the campus occurring during the day such as searching for food, photocopy and binding, where the dominance of the activity near/campus side (easy to reach) and some enter into the kampung approximately 400 meters from the campus (distance tired of students commuting to campus).

While at the time of the night domination of college student activities there are in around each boarding place (tempat kos) in the kampung in around the campus such as looking for food, looking for equipment/equipment tasks or photocopy/binding and find a laundry or laundry.

\section{Analysis of Production Re/production of Social Interaction Space In The Commodity Space Produced By Government Discourse, Citizens and Student Activities}

Based on the history (historicity) starting from the collapse of government discourse to the abstraction of citizens/homeowners/owners of capital/traders to the function of the building, the function of the land in around the campus changed its function by houseowners/citizens/capital owners/environmental community into function as a trade/comodity/space rented.

Commodity spaces result in the production of new spaces on the front yards house, on the streets, the formation of shops above the green spaces of the street by trading activities. The commodity spaces are closer to the daily activities of 
the college students (especially the main activities such as searching for food, for typing and photocopying/laundering clothes, laundry, etc). There is a new social interaction space that is produced from the main activities of everyday students with trading activities in around the campus.

Activities on commodity spaces (typing, photocopying, binding, food stalls,etc) are near the campus/on campus side only in the morning hours until the afternoon, while activities on the commodity space (typing, photocopy, binding, eating, laundry, gymnasium, barber shop, etc.) located near the boarding house (tempat kos) in the settlement activity can start from morning until night even until next morning, and so on.

\section{CONCLUSION}

Of the nine university in Jakarta, kampung Grogol and Kemanggisan are selected as kampung that has commodity space where there are homogeneity of trading activities and heterogenity of college student activities. The collapse of the government's discourse on the function of housing in the kampung in around the Binus and Untar by the abstraction of homeowners/capital owners and community environment due to dominated by factors of student needs in daily activities and opportunities of citizens/traders to seek profit.

The production of social interaction space in the commodity space is produced by the relation between the aspects that effec of commodity space (density of students, there is optimization of land use for function of building/either vertically/horizontally, changes in land use (occupancy to mixed trade), dominance homogeneity of trading activities and heterogenity/various of college student activities in kampung with the main type activities such as to/from campus, foraging (warung tegal, warung kopi,etc), looking for boarding house/guesthouse (tempat $k o s)$, laundry, typing, photocopying, binding, book store, and so on.

\section{REFERENCES}

Antoniades, A.C. (1990), Poetics of Architecture : Theory of Design. New York : Van Nostrand Reinhold.

Badan Pertanahan Nasional Republik Indonesia. (2017). Peta Pertanahan. http://BPN.go.id. Google.

Budihardjo, E. (1992), Sejumlah Masalah Pemukiman Kota. Alumni. Bandung.

Groat, Wang (2001), Architectural Research Methods. John Willey \& Sons ; USA.

Google. (2017). Google Map. Google

Government DKI Jakarta (1965). Master Plan DKI Jakarta. Jakarta. 
Pasaribu, Siahaan, Tobing : COMMODITIES SPACE FOR SOCIAL INTERACTION SPACE IN THE KAMPUNG AROUND CAMPUSES AT JAKARTA

Government DKI Jakarta (2005). Detail plan of Sub District Spatial Planning. Jakarta.

Government DKI Jakarta (2010). Municipal Spatial Plan DKI Jakarta. Jakarta.

Government DKI Jakarta (2005). Zonning Plan District. Jakarta.

Gehl, J. (2010), Cities For People. IslandPress. London.

Hoed, B. (2002), Semiotik dan Dinamika Sosial Budaya. Komunitas Bambu. Depok.

Knox, P., Pinch, S. (2010), Urban Social Geography. Prentice Hall. London.

Lefebvre, H. (1992), The Production of Space. Routledge. London.

Mulyana, Elly. Winarso, Haryo (2016). Karakteristik Kampung Kota Di Sekitar Perguruan Tinggi. Jurnal Perencanaan Wilayah dan Kota B SAPPK V5N2. ITB.

Rapoport, A. (1977), Human Aspects of Urban Form. Pergamon Press. England.

Sabaruddin, A. (2016), Permukiman Berkelanjutan. Telaah Psikologi Sosial. Erlangga. Jakarta.

Santoso, D.D (2007). Toleransi Keruangan Dalam Permukiman Padat, Studi Kasus Rumah Kontrakan Kampung Pajeksan dan JokonegaranYogyakarta. Disertasi. Jurusan Teknik Arsitektur dan Perencanaan Universitas Gajah Mada. Semarang. http://forumriset.wordpress.com.

Setiawan, Andi (2015). Produksi Ruang Sosial Sebagai Konsep Pengembangan Ruang Perkotaan. Jurnal FIB. Universitas Sebelas Maret.

Setiawan, B.H. (1995), Arsitektur Lingkungan dan Perilaku. Dirjen Dikti. Depdikbud RI. Indonesia.

Siahaan, U. (2013), Perencanaan Kota \& Permukiman. Jurusan Arsitektur Fakultas Teknik Universitas Kristen Indonesia.

Snyder, C.J., Catanese, J.A. (1991), Pengantar Arsitektur. Erlangga. Jakarta.

Simmel, G. (2004), The Sociology Of Space, Center for Spatially Integrated Social Science. Google ; escholarship.org University Of California.

Singarimbun (1995), Metode Penelitian Survey. Jakarta. LP3ES.

Siregar, A.S. (1992). Bandung-The Architecture of A City in Development. Katholieke Universiteit Leuven Faculteit Toegepaste Wetenschappen Departement Architectuur, Stedebouw En Afdeling Architectuur. Leuven.

Turner, J.F. (1976), Housing By People - Towards Autonomy In Building Environments, Marion Boyars Publishers Ltd, London 